\title{
Eco-Innovation and Firm Efficiency: Empirical Evidence from Slovenia
}

\author{
Jana Hojnik ${ }^{\text {a }}$ \\ Assistant Professor, Faculty of Management, jana.hojnik@fm-kp.si \\ Mitja Ruzzier ${ }^{a}$ \\ Professor, Faculty of Management, mitja.ruzzier@fm-kp.si \\ Tatiana Manolova ${ }^{b}$ \\ Associate Professor, tmanolova@bentley.edu \\ ${ }^{a}$ University of Primorska, Cankarjeva 5, 6000 Koper, Slovenia. \\ ${ }^{\mathrm{b}}$ Bentley University, 175 Forest St., Waltham, MA 02452, USA.
}

\begin{abstract}
$\mathrm{E}$ co-innovation plays an increasingly important role for the competitiveness of companies. It opens up new market opportunities due to the growing demand for eco-friendly products and can increase business efficiency. Using a dynamic capabilities lens, this article analyzes the relationships between various types of eco-innovation (product, process and organizational) and firm efficiency in the context of less innovative and more innovative companies. We use data from an online survey of Slovenian companies that have implemented eco-innovations as part of their operations. Statistical tests include an analysis of variance and a linear regression analysis.

We find that organizational eco-innovation positively affects firm efficiency at all companies independent of their innovation potential, while process eco-innovation is positively associated with firm efficiency only among more innovative companies. In addition, at less innovative

companies, firm age positively affects firm efficiency, suggesting that older and less innovative companies may enjoy learning curve benefits derived from experience. However, firm size has a positive effect on firm efficiency at more innovative companies, suggesting that more innovative companies may benefit from economies of scale. In general, more innovative companies are more likely to engage in eco-innovation and more likely to derive cost benefits (efficiency) from different types of eco-innovation.

The main limitations of our analysis are the subjective data on the level of firms' innovation and efficiency, the cross-sectional study design, and the single-country setting. Further in-depth longitudinal studies could better model the direction of causality between the implementation of eco-innovation and business efficiency, obtain objective data on business innovation, and ensure a more detailed and nuanced exploration of dynamic firm capabilities.
\end{abstract}

Keywords: eco-innovation; circular economy; firm efficiency; product eco-innovation; process eco-innovation; organizational eco-innovation; sustainability; more innovative companies; less innovative companies; Slovenia.
Citation: Hojnik J., Ruzzier M., Manolova T. (2017) EcoInnovation and Firm Efficiency: Empirical Evidence from Slovenia. Foresight and STI Governance, vol. 11, no 3, pp. 103-111. DOI: 10.17323/2500-2597.2017.3.103.111 
$\mathrm{T}$ o pursue and achieve environmental sustainability, companies around the world increasingly engage in eco-innovation. Eco-innovation is defined as the "introduction of any new or significantly improved product (good or service), process, organizational change or marketing solution that reduces the use of natural resources (including materials, energy, water and land) and decreases the release of harmful substances across the lifecycle" [European Commission, 2012, p. 8]. Eco-innovations facilitate the transition from a traditional or "linear" economy to an environmentally sustainable, "circular" economy. The circular economy is grounded in the three " $\mathrm{R}$ " principles-Reduce, Reuse and Recycle [Bourguignon, 2016; Ness, 2008; Su et al., 2013]. It promotes the adoption of closed-loop and cleaner production processes and increases the efficiency of resource use in order to achieve a better balance between and harmony among the three pillars of sustainability: economy, environment and society [Ghisellini et al., 2016]. Eco-innovations cannot be implemented successfully without environmental awareness and environmental responsibility on the part of both producers and consumers. Ample prior research demonstrates that both companies' environmental consciousness and customers' purchasing choices are needed in order to facilitate the transition to a more circular economy [Agan et al., 2013; Hojnik, Ruzzier, 2016b; Horbach et al., 2012; Li, 2014] $]^{1}$.

Although both consumers and producers are important stakeholders in the adoption of eco-innovation, there is tension in the process of creating and capturing environmental, social, and economic value. This is because the creation of customer value through eco-innovation does not guarantee the capture of economic value by the producer. Many consumers clearly derive tangible and intangible benefits from eco-innovations. Increasingly consumers are looking for environmentally friendly alternatives and are willing to pay higher prices for such products [Chen, 2013]. Thus, producers are expected to provide proper design, production, sales and recycling in order to meet consumers' demands for "green" products [Sarkar, 2013]. Consumers not only push companies to act in an environmentally responsible manner but also expect to reap private environmental benefits from eco-products such as cost and energy savings; improved product quality and durability; better repair, upgrade and disposal opportunities; and reduced health risks [Kammerer, 2009].

The effect of eco-innovation on producers' performance is far less clear. On the one hand, companies engaged in eco-innovation can derive cost savings by reducing raw material usage and energy dependency, which increases efficiency and improves competitiveness [EASAC, 2015]. The opportunity to realize cost savings (e.g., energy or material savings) is indeed one of the main reasons for investing in eco-innovations [Belin et al., 2011; Govindan et al., 2014; Horbach, 2008; Montabon et al., 2007). On the other hand, firm efficiency depends upon the type of eco-innovation, as only the most advanced eco-innovations will have the potential to generate cost savings and add to firm efficiency [Kesidou, Demirel, 2012]. In light of these tensions, we ask: (1) What specific types of companies are more likely to invest in eco-innovation? (2) What is the effect of different types of eco-innovation (i.e., product, process, and organizational) on firm efficiency?

To develop our theoretical argument, we build upon the dynamic capabilities perspective [Eisenhardt, Martin, 2000; Teece et al., 1997), which is an extension of the resource-based view [Piening, Salge, 2015; Wernerfelt, 1984]. We follow Teece et al's definition of dynamic capabilities as a firm's "ability to integrate, build, and reconfigure internal and external competences to address rapidly changing environments." [Teece et al., 1997, p. 516]. Our main premise is that more innovative companies are also more likely to engage in eco-innovation, as they already have developed capabilities for innovation. Furthermore, we expect that eco-innovation is more likely to lead to improved efficiency among more innovative companies. Our main contribution is an exploration of the effects of different types of eco-innovation (product, process and organizational) upon firm efficiency. In addition, we take a fine-grained approach and explore these effects in two sub-samples - more and less innovative companies - in order to provide more detailed insights into eco-innovation's effects on firm efficiency. Empirically, we contribute by documenting eco-innovation practices and their effect on firm efficiency in the context of Slovenia, a country that has successfully made the transition to an innovation-driven economy [WEF, 2016].

Slovenia provides a very appropriate study subject because it is both entrepreneur-friendly and environmentally-conscious. According to the latest GEM (Global Entrepreneurship Monitor) report, the level of perceived entrepreneurial opportunities in the country shows an upward trend. Slovenia also ranks high ( $22^{\text {nd }}$ out of 60 surveyed countries) with respect to the societal values concerning entrepreneurship, i.e., entrepreneurs are accorded high social status [GEM, 2016]. Slovenia ranks $15^{\text {th }}$ out of 139 countries in environmental performance, $12^{\text {th }}$ out of 138 in the number of ISO14001 environmental certificates issued, and $28^{\text {th }}$ out of 141 in the Global Innovation Index rankings [Dutta et al., 2016]. Thus, innovation, including eco-innovation, is becoming an indispensable part of Slovenian companies' strategies to survive and achieve a competitive advantage [Adalikwu, 2011].

Our paper proceeds as follows. In the next section, we set up the theoretical background and develop our research hypotheses. Then, we describe the study's methodology and sample characteristics and variables. The subsequent section reports upon the results, while the final section discusses this paper's implications for theory and practice.

\footnotetext{
See also the extensive literature review by [Hojnik, Ruzzier, 2016a].
} 


\section{Theoretical background and research hypotheses}

We grounded our argument in the dynamic capabilities perspective. Firm-level capabilities are conceptualized as the ability of a firm to perform an activity with predictable efficiency over time [Nelson, Winter, 1982]. Examples of firm-level capabilities include innovation, marketing, logistics, and customer service. Because capabilities are "invisible assets", and because some of the learning is difficult to articulate and transfer to other organizations [Teece, 1981], capabilities are firm-specific and are likely to provide a firm with a source of competitive advantage [Barney, 1991].

The capability view of a firm has been extended to the context of dynamic environments, with the idea that said firm's capabilities must be dynamic: companies must constantly adapt, reconfigure and renew their resources and capabilities in order to address environmental change and achieve congruence with the changing business environment [Teece et al., 1997]. Therefore, dynamic capabilities have been defined as the company's potential to systematically solve problems, sense opportunities and threats, make timely decisions, and implement strategic decisions and changes efficiently to ensure that the company is following the right path [Li, Liu, 2014, p. 2793]. Dynamic capabilities are thus related to organizational change that promotes innovation and, as a result, improves the company's evolutionary fitness [Makkonen et al., 2014]. The dynamic capabilities perspective garnered much attention because a resource-based strategy grounded on the simple accumulation of valuable assets/resources, protected by an aggressive intellectual property stance, proved inadequate to support a significant competitive advantage [Teece et al., 1997]. To be globally competitive, companies need to demonstrate responsiveness and rapid, flexible product innovation, coupled with the management capability to effectively coordinate and redeploy market positions and expansion paths [Teece et al., 1997].

Applying the dynamic capability perspective to the context of eco-innovation, we can expect that these companies that have already developed a firm-level innovation capability to find it easier to engage in ecoinnovation. This is because these companies already have innovation experience, well-established routines, and task-management processes in place. In addition, firms that have innovation capabilities are likely to have developed the skills to articulate, codify, share, and internalize innovation-related knowledge, which can be successfully transferred and used for the launch of eco-innovations. Formally, we hypothesize:

Hypothesis 1: More innovative companies will demonstrate higher levels of eco-innovation compared to less innovative companies.

Cost savings are among the main reasons for companies to invest in eco-innovation [Belin et al., 2011; Horbach, 2008]. Eco-innovation and better environmental performance can lead to the reduction of several expenditures, especially in the following areas: cost of materials, energy and services; cost of capital; cost of labor; risk management and relations with external stakeholders [Ambec, Lanoie, 2008]. Based on a study of SMEs, Klewitz [Klewitz, 2012] found that companies can benefit from cost savings (increased energy efficiency) when dealing with sustainability-related issues. Large financial gains can thus be derived from energy and material saving, waste reduction, and addressing lifecycle costs [Shrivastava, 1995]. Environmental management practices associated with cost savings include recycling (more efficient use of materials tends to reduce the cost structure), proactive waste reduction, and remanufacture (both focus on lowering cost structure) [Montabon et al., 2007]. Companies have acknowledged that reuse leads to lower costs (i.e., instead of purchasing new materials, they reuse materials and thus are able to lower costs) [Govindan et al., 2014]. However, not all eco-innovations pay off. Cost savings associated with firm efficiency, which can be attained through the successful implementation of eco-innovation, depend upon the type of eco-innovation. This means that cost savings are most closely associated with the most advanced ecoinnovations, which encompass the elimination/reduction or reuse of material waste, while less advanced eco-innovations have a lower potential for creating cost savings and contributing to firm efficiency [Kesidou, Demirel, 2012]. Although empirical results are mixed, the majority of research points out the significance of cost savings for process eco-innovations [Triguero et al., 2013]. In addition, environmental technologies have the potential to decrease operating costs by exploiting ecological efficiencies [Shrivastava, 1995]. Overall, companies that focus on green product, process and managerial innovations are likely to increase their savings, efficiency, and productivity [Chiou et al., 2011]. Formally, we hypothesize:

Hypothesis 2: Eco-innovation will positively impact firm efficiency.

\section{Methodology \\ Data collection and sample}

The main objective of this study is to explore the relationship between different types of eco-innovation (product, process and organizational eco-innovations) and firm efficiency. Data on specific types of ecoinnovation at the firm level are usually not available from published sources. To overcome this difficulty, we used a survey (an e-mail questionnaire distributed to environmental managers and directors of Slovenian companies that use eco-innovations within their entrepreneurial activity), which we sent out in November 2014. The survey was e-mailed along with a cover letter explaining the general purpose of the study, and anonymity was guaranteed in order to increase the response rate. A comprehensive literature review was undertaken prior to designing the survey instrument to ensure the reliability and validity of the measures. 
In addition, prior to data collection, the survey was pre-tested for content validity. First, eight experienced researchers were asked to critique the questionnaire for ambiguity, clarity and appropriateness of the used terminology. Second, we asked five environmental managers to discuss the questionnaire, comment on term appropriateness and identify any vagueness. Based on their feedback, the questionnaire was adjusted. Over a three-month period (November 2014 through February 2015) and after three reminders, we collected 223 completed questionnaires out of the 6,564 companies to which we sent the questionnaire, resulting in a response rate of $3.40 \%$. A low response rate was expected, since the questionnaire was only available online and only companies that engage in eco-innovation activities were asked to respond (in order to avoid excluding any companies that are active in eco-innovation, the questionnaire was sent to the entire population of companies).

As we discuss in more detail below, the sample was next divided into two sub-samples: more innovative companies $(\mathrm{N}=125$ companies $)$ and less innovative companies $(\mathrm{N}=98$ companies $)$. Table 1 reports the characteristics of the two sub-samples.

The two sub-samples differ in size distribution. ${ }^{2}$ The subsample of less innovative companies includes more micro companies (32 companies) and fewer large companies (14 companies), while in the subsample of the more innovative companies the situation is reversed (there are 33 large companies and only 20 micro companies). The majority of the companies in both sub-samples are 20 or more years old. With respect to industry distribution, more innovative companies are predominantly in manufacturing, while less innovative companies operate mainly in service-related industries. All companies in the analyzed sample deploy some sort of eco-innovation, however, the more innovative companies are more likely to have garnered environmental certificates (EMAS or ISO14001).

\section{Variables}

Both the dependent and independent variables are measured using multi-item scales. Prior to running the regression calculations, we ascertained the validity and reliability of the measurement model using factor and reliability analysis. We factor-analyzed each of our independent variables, i.e., eco-innovation type (e.g., product, process, or organizational eco-innovation) and our dependent variable, firm efficiency (the extraction method was Maximum Likelihood, and the rotation was Direct Oblimin).

Product eco-innovation was measured using a six-item, seven-point Likert-type scale, adapted from [Chen et al., 2006; Chen, 2008; Chiou et al., 2011] and ranging from 1 ("strongly disagree") to 7 ("strongly agree"), with 4 as the neutral anchor. We first conducted an exploratory factor analysis, which showed that all six items loaded on a common factor - product eco-innovation. The value of the Kaiser-Meyer-Olkin (KMO) measure for sampling adequacy was 0.846 , which can be interpreted as excellent, because it is above 0.80 and suggests that there are high enough correlations between variables for suitable use of factor analysis. In addition, Bartlett's test of sphericity showed a statistically significant value (chi-square $=712.159$;

Table 1. Sample characteristics

\begin{tabular}{|c|c|c|c|c|c|}
\hline & \multirow{3}{*}{ Characteristics } & \multicolumn{4}{|c|}{ Firm's Innovativeness Level } \\
\hline & & \multicolumn{2}{|c|}{ Low (98 companies) } & \multicolumn{2}{|c|}{ High (125 companies) } \\
\hline & & $\begin{array}{l}\text { Number of } \\
\text { companies }\end{array}$ & Percentage & $\begin{array}{l}\text { Number of } \\
\text { companies }\end{array}$ & Percentage \\
\hline \multirow{4}{*}{ Firm size } & Micro company & 32 & 32.7 & 20 & 16 \\
\hline & Small company & 30 & 30.6 & 38 & 30.4 \\
\hline & Medium company & 22 & 22.4 & 34 & 27.2 \\
\hline & Large company & 14 & 14.3 & 33 & 26.4 \\
\hline \multirow{4}{*}{ Firm age } & 3 years or fewer & 1 & 1 & 3 & 2.4 \\
\hline & $4-9$ years & 9 & 9.2 & 6 & 4.8 \\
\hline & $10-19$ years & 21 & 21.4 & 18 & 14.4 \\
\hline & 20 years and more & 67 & 68.4 & 96 & 76.8 \\
\hline \multirow{2}{*}{ Type of industry } & Service industry & 79 & 80.6 & 53 & 42.4 \\
\hline & Manufacturing industry & 19 & 19.4 & 72 & 57.6 \\
\hline \multirow{3}{*}{$\begin{array}{l}\text { Type of commerce } \\
\text { transactions }\end{array}$} & Business-to-business (B2B) & 58 & 59.2 & 55 & 44 \\
\hline & Business-to-customer (B2C) & 40 & 40.8 & 69 & 55.2 \\
\hline & Both (B2B and B2C) & - & - & 1 & 0.8 \\
\hline \multicolumn{2}{|c|}{ Internationalization (operating on foreign markets) } & 52 & 53.1 & 99 & 79.2 \\
\hline \multicolumn{2}{|c|}{ Have EMAS environmental certificate } & 1 & 1 & 3 & 2.4 \\
\hline \multicolumn{2}{|c|}{ Have ISO 14001 environmental certificate } & 28 & 28.6 & 58 & 46.4 \\
\hline
\end{tabular}

2 We used the European firm size classification criteria, as follows: micro companies (fewer than 10 employees); small companies (10-49 employees); medium-sized companies (50-249 employees); and large companies (250 employees and above). See http:// ec.europa.eu/eurostat/statistics-explained/index.php/Glossary:Enterprise_size. 
$\mathrm{df}=15 ; \mathrm{p}=0.000$ ), meaning that the correlation matrix has significant correlations. The communality index showed good communalities for almost all items (above the threshold of 0.2 ), and the explained variance is estimated to be $55.245 \%$.

Five items measured process eco-innovation [Chen et al., 2006; Chen, 2008; Chiou et al., 2011]. The exploratory factor analysis also extracted a single factor, which explained $68.441 \%$ of total variance. The Kaiser-Meyer-Olkin measure for sampling adequacy $(\mathrm{KMO}=0.861)$ and Bartlett's test of sphericity (chisquare $=807.261 ; \mathrm{df}=10 ; \mathrm{p}=0.000)$ showed good results.

Six items were used to measure organizational eco-innovation [Cheng, Shiu, 2012]. The exploratory factor analysis extracted a single factor which explained $78.368 \%$ of the total variance. The Kaiser-Meyer-Olkin measure for sampling adequacy $(\mathrm{KMO}=0.901)$ and Bartlett's test of sphericity $($ chi-square $=1454.634 ; \mathrm{df}=$ $15 ; \mathrm{p}=0.000)$ also showed good results.

Following Sharma and Vredenburg [Sharma, Vredenburg, 1998], we measured efficiency (our dependent variable) with a six-item, seven-point Likert-type scale. An exploratory factor analysis was conducted, and regression factor scores were saved and used in further analysis, as for all eco-innovation types. The extraction method used was Maximum Likelihood, and the rotation was Direct Oblimin. The exploratory factor analysis for firm efficiency also extracted only one factor, explaining $71.637 \%$ of the total variance. The Kaiser-Meyer-Olkin measure for sampling adequacy $(\mathrm{KMO}=0.860)$ and Bartlett's test of sphericity (chi-square $=1275.002 ; \mathrm{df}=15 ; \mathrm{p}=0.000$ ) showed good results.

The results from the factor analysis are reported in Tables 2 and 3.

Since we are interested in whether more innovative companies are also more likely to develop eco-innovation, we introduced a grouping variable, "company innovativeness". We identified whether a company is more or less innovative based on the following three statements: 1) Company has launched a new product or service at the global level; 2) Company has launched a new product or service in the company's offering, even though similar products or services already exist on the market; and 3) Company has expanded the present offering with new types. Companies were asked to estimate to what extent the above statements held true for them (using a 7 -point Likert-type scale, ranging from $1=$ not true at all to $7=$ completely true). We classified companies as more or less innovative by a median split of the sample (the three items were summed up and divided by three). In our regression estimations, we also controlled for firm size, firm age and type of industry.

\section{Table 2. Description of factor items and their loadings}

\begin{tabular}{|c|c|}
\hline Items & Factor item loadings \\
\hline \multicolumn{2}{|l|}{ Product eco-innovation } \\
\hline The company is using environmentally friendly materials & 0.888 \\
\hline The company is improving and designing environmentally friendly packaging for existing and new products & 0.866 \\
\hline The company is recovering the company's end-of-life products and recycling & 0.811 \\
\hline $\begin{array}{l}\text { The company chooses product materials that consume the least possible amount of energy and resources for } \\
\text { conducting product development or design }\end{array}$ & 0.659 \\
\hline $\begin{array}{l}\text { The company uses the smallest possible amount of materials to create the product for conducting product } \\
\text { development or design }\end{array}$ & 0.634 \\
\hline $\begin{array}{l}\text { The company deliberately evaluates whether the product is easy to recycle, reuse and decompose when } \\
\text { conducting product development or design }\end{array}$ & 0.532 \\
\hline \multicolumn{2}{|l|}{ Process eco-innovation } \\
\hline Low energy consumption of materials such as water, electricity, gas and petrol during production/use/disposal & 0.924 \\
\hline Recycle, reuse and remanufacture of materials & 0.909 \\
\hline Use of cleaner technology to generate savings and prevent pollution & 0.808 \\
\hline The manufacturing process of the company effectively reduces the emission of hazardous substances or waste & 0.758 \\
\hline The manufacturing process of the company reduces the use of raw materials & 0.716 \\
\hline \multicolumn{2}{|l|}{ Organizational eco-innovation } \\
\hline Our firm management often uses novel systems to manage eco-innovation & 0.930 \\
\hline Our firm management often collects information on eco-innovation trends & 0.929 \\
\hline Our firm management often actively engages in eco-innovation activities & 0.891 \\
\hline Our firm management often communicates about eco-innovation information with our employees & 0.888 \\
\hline Our firm management often invests substantially in R\&D on eco-innovation & 0.866 \\
\hline $\begin{array}{l}\text { Our firm management often communicates about experiences among various departments involved in eco- } \\
\text { innovation }\end{array}$ & 0.801 \\
\hline \multicolumn{2}{|l|}{ Firm efficiency } \\
\hline Reduction in material costs & 0.919 \\
\hline Reduction in process/production costs & 0.908 \\
\hline Increased process/production efficiency & 0.839 \\
\hline Increased productivity & 0.816 \\
\hline Increased knowledge about effective ways to manage operations & 0.812 \\
\hline Improved product quality & 0.774 \\
\hline
\end{tabular}


Table 3. General characteristics of factors

\begin{tabular}{|l|c|c|c|}
\hline \multicolumn{1}{|c|}{ Factors } & Number of factors extracted & Eigen- value & Cronbach's alpha \\
\hline Product eco-innovation & 1 & 3.735 & 0.866 \\
\hline Process eco-innovation & 1 & 3.739 & 0.912 \\
\hline Organizational eco-innovation & 1 & 4.919 & 0.956 \\
\hline Firm efficiency & 1 & 4.583 & 0.938 \\
\hline Source: compiled by the authors. & & \\
\hline
\end{tabular}

Before proceeding with the regression analysis, we checked for multicollinearity. We examined the Variance Inflation Factor (VIF), which is a widely used measure of the degree of multicollinearity of the $i$-th independent variable with the other independent variables in a regression model [O'Brien, 2007]. Various rules of thumb for values of VIF have appeared in the literature (rule of 4, rule of 10, etc.); however, when the VIF exceeds these values, these rules often are interpreted as casting doubt on the results of the regression analysis [O'Brien, 2007]. In our case, all VIF values were below the recommended threshold of 4, alleviating multicollinearity concerns (the highest VIF value was 2.539, and the lowest VIF value was 1.056).

Table 4 reports the means, standard deviations, and correlations for all variables entered into the regression analysis.

\section{Results}

We tested Hypothesis 1 by running an analysis of variance ( $t$ test). We found significant differences between less and more innovative companies across all three types of eco-innovation (product, process and organizational eco-innovation). The results are reported in Table 5. Thus, Hypothesis 1, which stated that more innovative companies would demonstrate higher levels of eco-innovation compared to less innovative companies, was fully supported.

In order to test the relationship between the different types of eco-innovation and firm efficiency, we continued with a linear regression analysis. In addition to testing the main relationship between ecoinnovation and firm efficiency, we also controlled for the effects of various factors that may affect firm efficiency (firm size, firm age and type of industry in which the firm operates). Linear regression analysis was conducted separately for each sub-sample, that is, for the less innovative companies (Table 6) and the more innovative companies (Table 7).

For the sub-sample of less innovative companies (Table 6), the tested model is statistically significant $(\mathrm{sig}=0.000 ; \mathrm{F}=6.803)$. Organizational eco-innovation is significantly and positively associated with firm efficiency while the other two types of eco-innovation (i.e., product and process eco-innovation) do not exert a statistically significant effect on firm efficiency. Among the control variables (firm age, firm size and type of industry), only firm age has a significant effect on firm efficiency while neither firm size nor type of industry affect firm efficiency at less innovative companies.

In the sub-sample of more innovative companies (Table 7), the model is also statistically significant (sig = $0.000 ; \mathrm{F}=12.000$ ). Results indicate a positive and significant effect of both process and organizational eco-innovation on firm efficiency. However, we do not find any significant relationship between product

\section{Table 4. Correlations, means and standard deviations of all variables}

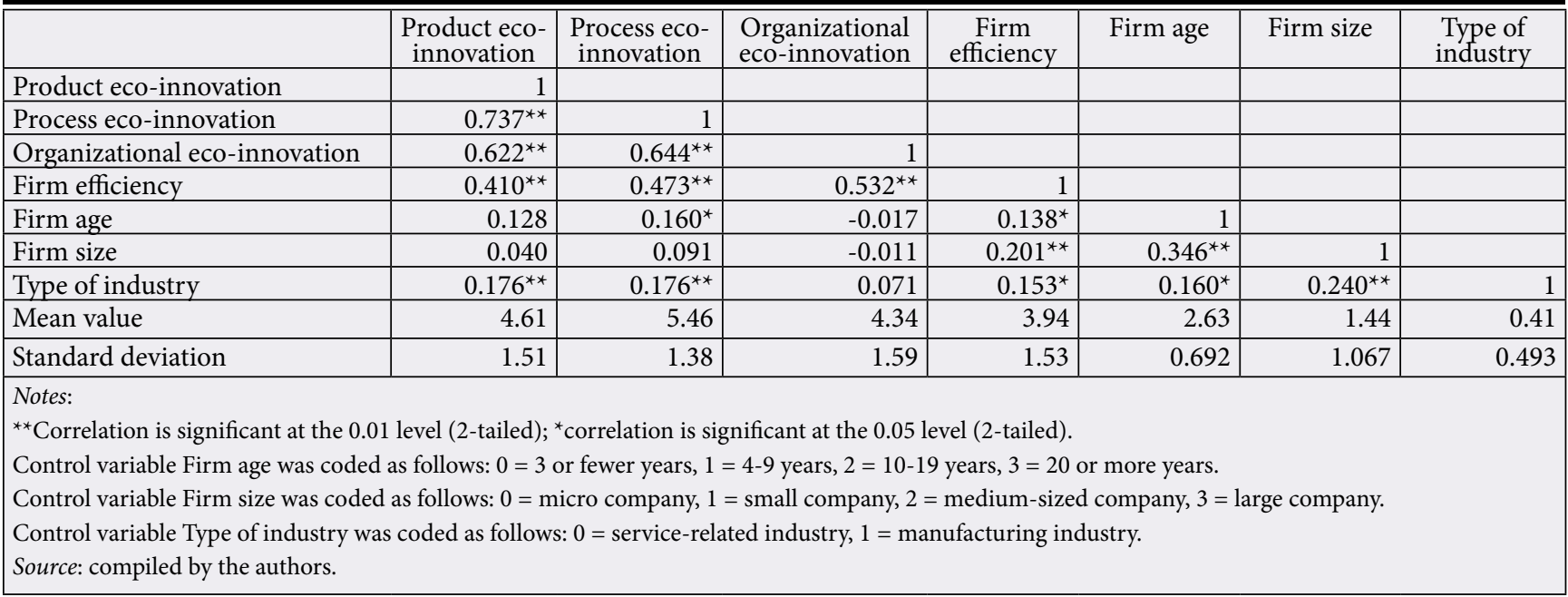




\section{Table 5. The results of the $t$ test for the two sub-samples based on company innovativeness} (sub-groups of less innovative companies and more innovative companies)

\begin{tabular}{|c|c|c|c|c|c|}
\hline \multirow{3}{*}{ Variables } & \multicolumn{4}{|c|}{ Firm's Innovativeness Level } & \multirow{3}{*}{$t$-test } \\
\hline & \multicolumn{2}{|c|}{ Low } & \multicolumn{2}{|c|}{ High } & \\
\hline & Mean & SD & Mean & SD & \\
\hline Product eco-innovation & 4.21 & 1.57 & 4.92 & 1.39 & $-3.582^{\star *}$ \\
\hline Process eco-innovation & 5.09 & 1.45 & 5.75 & 1.25 & $-3.633^{* *}$ \\
\hline Organizational eco-innovation & 3.83 & 1.54 & 4.74 & 1.52 & $-4.407^{\star *}$ \\
\hline
\end{tabular}

eco-innovation and firm efficiency; this indicates that, similar to less innovative companies, product ecoinnovation also does not contribute to firm efficiency at more innovative companies. When controlling for the effect of various factors such as firm size, firm age and type of industry, we find that only firm size has a positive effect on firm efficiency, while firm age and type of industry do not have a significant effect.

Collectively, the results from the two regression estimations provide partial support for Hypothesis 2, as in both sub-samples some types of eco-innovation are positively associated with firm efficiency. Furthermore, the association between eco-innovation and firm efficiency is more robust in the sub-sample of more innovative companies, in that both organizational and process eco-innovations positively affect firm efficiency, whereas in the sub-sample of less innovative companies only organizational eco-innovation demonstrates a significantly positive effect.

\section{Discussion and conclusions}

Based on the empirical evidence provided above, we can conclude that more innovative companies demonstrate higher levels of eco-innovation compared to less innovative companies. This supports the dynamic capability explanation [Teece et al., 1997] which posits that more innovative companies will demonstrate higher levels of eco-innovation compared to less innovative companies because they have already developed the requisite processes for engaging in, completing, sharing, and storing the outputs from the innovative process. In addition, more innovative companies tend to be more likely to implement more complex eco-innovation types (such as process eco-innovations) and also appear to be more capable of reaping benefits from the implementation of eco-innovations. Our results indicate that at more innovative companies, two types of eco-innovation - process and organizational eco-innovation - lead to better firm efficiency, while at less innovative companies, only organizational eco-innovation contributes to firm efficiency. It is also worth noting that organizational innovation is the least complex form of eco-innovation, as it requires fewer resources (human and financial) and knowledge.

Our finding that process eco-innovation positively affects firm efficiency at more innovative companies is in line with the findings of [Triguero et al., 2013]. Furthermore, we found empirical evidence that organizational eco-innovation positively affects firm efficiency at both more and less innovative companies, which corresponds to the findings of [Chiou et al., 2011]. However, we did not find any empirical evidence to support the notion that product eco-innovation contributes to firm efficiency, for which prior research [Chiou et al., 2011] found a positive link.

In addition, when controlling for the effects of firm size, firm age and type of industry, we found that, at less innovative companies, firm age has a positive effect on firm efficiency, while at more innovative companies, it is firm size that affects firm efficiency. It appears that among less innovative companies, older companies are more efficient than younger ones. The reason for this may be that older companies have already gained

\section{Table 6. OLS Regression Estimates of the Effects on Firm Efficiency (Less Innovative} Companies)

\begin{tabular}{|c|c|c|c|c|c|}
\hline \multirow{2}{*}{ Model } & \multicolumn{2}{|c|}{$\begin{array}{l}\text { Unstandardized } \\
\text { Coefficients }\end{array}$} & \multirow{2}{*}{$\begin{array}{c}\begin{array}{c}\text { Standardized } \\
\text { Coefficients }\end{array} \\
\text { Beta }\end{array}$} & \multirow[t]{2}{*}{$t$-test } & \multirow{2}{*}{ Sig. } \\
\hline & \begin{tabular}{l|l}
$\mathbf{B}$ & \\
\end{tabular} & Std. Error & & & \\
\hline (Constant) & -0.997 & 0.323 & & -3.086 & 0.003 \\
\hline Product eco-innovation & 0.168 & 0.121 & 0.175 & 1.386 & 0.169 \\
\hline Process eco-innovation & -0.005 & 0.126 & -0.006 & -0.041 & 0.967 \\
\hline Organizational eco-innovation & 0.402 & 0.117 & 0.406 & 3.432 & $0.001^{*}$ \\
\hline Firm age & 0.312 & 0.132 & 0.231 & 2.373 & $0.020^{*}$ \\
\hline Firm size & 0.107 & 0.085 & 0.118 & 1.254 & 0.213 \\
\hline Type of industry & 0.025 & 0.229 & 0.010 & 0.108 & 0.914 \\
\hline
\end{tabular}

Notes: Dependent variable: firm efficiency, ${ }^{*} \mathrm{p}<0.05$

Source: compiled by the authors. 


\begin{tabular}{|c|c|c|c|c|c|}
\hline \multirow{2}{*}{ Model } & \multicolumn{2}{|c|}{$\begin{array}{l}\text { Unstandardized } \\
\text { Coefficients }\end{array}$} & \multirow{2}{*}{$\begin{array}{c}\begin{array}{c}\text { Standardized } \\
\text { Coefficients }\end{array} \\
\text { Beta }\end{array}$} & \multirow[t]{2}{*}{$t$-test } & \multirow{2}{*}{ Sig. } \\
\hline & B & Std. Error & & & \\
\hline (Constant) & 0.022 & 0.295 & & 0.074 & 0.941 \\
\hline Product eco-innovation & -0.172 & 0.126 & -0.154 & -1.369 & 0.174 \\
\hline Process eco-innovation & 0.357 & 0.130 & 0.316 & 2.753 & $0.007^{\star}$ \\
\hline Organizational eco-innovation & 0.460 & 0.106 & 0.449 & 4.335 & $0.000^{*}$ \\
\hline Firm age & -0.114 & 0.112 & -0.081 & -1.015 & 0.312 \\
\hline Firm size & 0.174 & 0.074 & 0.191 & 2.359 & $0.020^{\star}$ \\
\hline Type of industry & 0.074 & 0.145 & 0.038 & 0.506 & 0.614 \\
\hline
\end{tabular}

trust, market position, and a reputation on the market in addition to knowledge of how to become more efficient in their operations. Among more innovative companies, however, firm size has a positive effect on firm efficiency; that is, the larger the company, the greater the firm efficiency. In sum, less innovative companies may have learning curve economies, whereas more innovative companies may enjoy economies of scale.

Our study is not without limitations, which need to be taken into consideration when interpreting its results. First, the cross-sectional research design does not permit us to ascertain the direction of causality. Thus, our findings should be considered exploratory and be further confirmed through a longitudinal study design so as to better model the direction of causality. Second, we only have data from a single country. Still, we believe our results are generalizable to economies similar to Slovenia with regard to the level of economic development and economic structure. Third, we have subjective data on the level of innovation and efficiency. A fruitful direction for future research would be to corroborate our findings using objective data on firm innovation (including eco-innovation) and firm performance. In addition, future research should also consider and directly measure dynamic capabilities, which could work as an antecedent of the relationship between eco-innovation and firm efficiency. As such, we could precisely determine which factors contribute to the eco-innovation effect on firm efficiency. Moreover, the model could be tested by employing structural equation modeling on a larger sample in order to explore the differences between more and less innovative companies.

Limitations notwithstanding, our exploratory study has implications for both management theory and managerial practice. To start with, our study strongly suggests that more innovative companies are also more likely to implement eco-innovations. An important managerial implication from our findings is that companies should invest more in innovation and be more open to eco-innovation, for two reasons. First, eco-innovation opens up new market opportunities (through the deployment of different types of innovations) and second, eco-innovation has the potential to improve firm efficiency and, consequently, to increase a company's competitiveness. Further, we find that, at more innovative companies, both process and organizational eco-innovations lead to better firm efficiency, while at less innovative companies, only organizational eco-innovation contributes to firm efficiency. Based on these findings, we suggest that managers should invest more in innovation generally, because a more innovative company is more likely to deploy other types of innovation, such as eco-innovations in this case. This, in turn, will lead to greater firm efficiency, since eco-innovations (process and organizational eco-innovation) positively contribute to firm efficiency. Finally, with regard to management theory, future research should be oriented towards a finer-grained exploration of dynamic capabilities, which seem to represent a strong foundation for more innovative companies. Our findings imply that, when exploring the effects of eco-innovation on business performance or, in our case, on firm efficiency, we should also consider the innovativeness of the company and distinguish between more innovative and less innovative companies. More innovative companies are likely to invest more aggressively in eco-innovation and probably deploy more advanced types of ecoinnovations, which in turn has a positive effect on firm efficiency.

\section{References}

Adalikwu C. (2011) Impact of international and home-based research and development (R\&D) on innovation performance. International Journal of Human Sciences, vol. 8, no 2, pp. 474-498.

Agan Y., Acar M.F., Borodin A. (2013) Drivers of environmental processes and their impact on performance: A study of Turkish SMEs. Journal of Cleaner Production, vol. 51, pp. 23-33. DOI: 10.1016/j.jclepro.2012.12.043.

Ambec S., Lanoie P. (2008) Does It Pay to Be Green? A Systematic Overview. The Academy of Management Perspectives, vol. 22, no 4, pp. 45-62.

Barney J. (1991) Firm Resources and Sustained Competitive Advantage. Journal of Management, vol. 17, no 1, pp. 99 120. DOI: $10.1177 / 014920639101700108$.

Belin J., Horbach J., Oltra V. (2011) Determinants and Specificities of Eco-innovations - An Econometric Analysis for the French and German Industry Based on the Community Innovation Survey (GREThA Discussion Paper 2011-17), Bordeaux: Université Montesquieu Bordeaux IV. Available at: http://ideas.repec.org/p/grt/wpegrt/2011-17.html, accessed 26.06.2013. 
Bourguignon D. (2016) Closing the loop: New circular economy package, Brussels: European Parliament.

Chen Y.-S. (2008) The Driver of Green Innovation and Green Image - Green Core Competence. Journal of Business Ethics, vol. 81, no 3, pp. 531-543.

Chen Y.-S. (2013) Towards green trust: The influences of green perceived quality, green perceived risk, and green satisfaction. Management Decision, vol. 51, no 1, pp. 63-82. DOI: 10.1108/00251741311291319.

Chen Y.-S., Lai S.-B., Wen C.-T. (2006) The Influence of Green Innovation Performance on Corporate Advantage in Taiwan. Journal of Business Ethics, vol. 67, no 4, pp. 331-339.

Cheng C.C., Shiu E.C. (2012) Validation of a proposed instrument for measuring eco-innovation: An implementation perspective. Technovation, vol. 32, no 6, pp. 329-344. DOI: 10.1016/j.technovation.2012.02.001.

Chiou T.-Y., Chan H.K., Lettice F., Chung S.H. (2011) The influence of greening the suppliers and green innovation on environmental performance and competitive advantage in Taiwan. Transportation Research Part E: Logistics and Transportation Review, vol. 47, no 6, pp. 822-836. DOI: 10.1016/j.tre.2011.05.016.

Dutta S., Lanvin B., Wunsch-Vincent S. (eds.) (2016) The Global Innovation Index 2016. Winning with Global Innovation, Cornell University, INSEAD, World Intellectual Property Organisation. Available at: http://www.wipo.int/edocs/ pubdocs/en/wipo_pub_gii_2016.pdf, accessed 16.05.2017.

EASAC (2015) Circular economy: A commentary from the perspectives of the natural and social sciences, Brussels: European Academies' Science Advisory Council.

Eisenhardt K.M., Martin J.A. (2000) Dynamic Capabilities: What Are They? Strategic Management Journal, vol. 21, no $10-11$, pp. $1105-1121$.

European Commission (2012) Eco-Innovation Observatory. Methodological Report, Brussels: European Commission. Available at: http://www.eco-innovation.eu/images/stories/Reports/eio_methodological_report_2012.pdf, accessed 26.06.2014.

Ghisellini P., Cialani C., Ulgiati S. (2016) A review on circular economy: The expected transition to a balanced interplay of environmental and economic systems. Journal of Cleaner Production, vol. 114, pp. 11-32. DOI: 10.1016/j. jclepro.2015.09.007.

Govindan K., Diabat A. Madan Shankar K. (2014) Analyzing the drivers of green manufacturing with fuzzy approach. Journal of Cleaner Production, vol. 96, no 1, pp. 182-193. DOI: 10.1016/j.jclepro.2014.02.054.

Hojnik J., Ruzzier M. (2016a) What drives eco-innovation? A review of an emerging literature. Environmental Innovation and Societal Transitions, vol. 19, pp. 31-41. DOI: http://dx.doi.org/10.1016/j.eist.2015.09.006.

Hojnik J., Ruzzier M. (2016) The driving forces of process eco-innovation and its impact on performance: Insights from Slovenia. Journal of Cleaner Production, vol. 133, pp. 812-825. DOI: 10.1016/j.jclepro.2016.06.002.

Horbach J. (2008) Determinants of environmental innovation - New evidence from German panel data sources. Research Policy, vol. 37, no 1, pp. 163-173. DOI: 10.1016/j.respol.2007.08.006.

Horbach J., Rammer C., Rennings K. (2012) Determinants of eco-innovations by type of environmental impact The role of regulatory push/pull, technology push and market pull. Ecological Economics, vol. 78, pp. 112-122. DOI: 10.1016/j.ecolecon.2012.04.005.

Kammerer D. (2009) The effects of customer benefit and regulation on environmental product innovation. Ecological Economics, vol. 68, no 8-9, pp. 2285-2295. DOI: 10.1016/j.ecolecon.2009.02.016.

Kesidou E., Demirel P. (2012) On the drivers of eco-innovations: Empirical evidence from the UK. Research Policy, vol. 41, no 5, pp. 862-870. DOI: 10.1016/j.respol.2012.01.005.

Klewitz J. (2012) Intermediaries driving eco-innovation in SMEs: A qualitative investigation. European Journal of Innovation Management, vol. 15, no 4, pp. 442-467. DOI: 10.1108/14601061211272376.

Li D., Liu J. (2014) Dynamic capabilities, environmental dynamism, and competitive advantage: Evidence from China. Journal of Business Research, vol. 67, no 1, pp. 2793-2799. DOI: 10.1016/j.jbusres.2012.08.007.

Li Y. (2014) Environmental innovation practices and performance: Moderating effect of resource commitment. Journal of Cleaner Production, vol. 66, pp. 450-458. DOI: 10.1016/j.jclepro.2013.11.044.

Makkonen H., Pohjola M., Olkkonen R., Koponen A. (2014) Dynamic capabilities and firm performance in a financial crisis. Journal of Business Research, vol. 67, no 1, pp. 2707-2719. DOI: 10.1016/j.jbusres.2013.03.020.

Montabon F., Sroufe R., Narasimhan R. (2007) An examination of corporate reporting, environmental management practices and firm performance. Journal of Operations Management, vol. 25, no 5, pp. 998-1014. DOI: 10.1016/j. jom.2006.10.003.

Nelson R.R., Winter S.G. (1982) An Evolutionary Theory of Economic Change, Cambridge, MA: Harvard University Press.

Ness D. (2008) Sustainable urban infrastructure in China: Towards a factor 10 improvement in resource productivity through integrated infrastructure system. International Journal of Sustainable Development and World Ecology, vol. 15, no 4, pp. 288-301.

O’Brien R.M. (2007) A caution regarding rules of thumb for variance inflation factors. Quality and Quantity, vol. 41, no 5, pp. 673-690. DOI: 10.1007/s11135-006-9018-6.

Piening E.P., Salge T.O. (2015) Understanding the Antecedents, Contingencies, and Performance Implications of Process Innovation: A Dynamic Capabilities Perspective. Journal of Product Innovation Management, vol. 32, no 1, pp. 80-97. DOI: $10.1111 /$ jpim.12225.

Sarkar A.N. (2013) Promotion of eco-innovation to leverage sustainable development of eco-industry and green growth. International Journal of Ecology and Development, vol. 25, no 2, pp. 71-104. Available at: http://www.ecsdev.org/ojs/ index.php/ejsd/article/view/48, accessed 12.06.2017.

Sharma S., Vredenburg H. (1998) Proactive corporate environmental strategy and the development of competitively valuable organizational capabilities. Strategic Management Journal, vol. 19, pp. 729-753.

Shrivastava P. (1995) Environmental technologies and competitive advantage. Strategic Management Journal, vol. 16, no S1, pp. 183-200. Available at: http://onlinelibrary.wiley.com/doi/10.1002/smj.4250160923/abstract, accessed 23.02.2014.

Su B., Heshmati A., Geng Y., Yu X. (2013) A review of the circular economy in China: Moving from rethoric to implementation. Journal of Cleaner Production, vol. 42, pp. 215-277.

Teece D.J. (1981) The market for know-how and the efficient international transfer of technology. Annals of the Academy of Political and Social Science, vol. 458, pp. 81-96.

Teece D.J., Pisano G., Shuen A. (1997) Dynamic capabilities and strategic management. Strategic Management Journal, vol. 18, no 7, pp. 509-533. DOI: 10.1142/9789812834478_0002.

Triguero A., Moreno-Mondéjar L., Davia M.A. (2013) Drivers of different types of eco-innovation in European SMEs. Ecological Economics, vol. 92, pp. 25-33. DOI: 10.1016/j.ecolecon.2013.04.009.

Wernerfelt B. (1984) A resource-based view of the firm. Strategic Management Journal, vol. 5, no 2, pp. 171-180.

World Economic Forum (2016) Stages of development and the weighted index. Available at: http://reports.weforum. org/global-competitiveness-report-2014-2015/methodology, accessed 17.01.2017. 